International Journal of Language Education

Volume 5, Number 3, 2021, pp. 152-164

ISSN: $2548-8457$ (Print) 2548-8465 (Online)

Doi: https://doi.org/10.26858/ijole.v5i3.16258

\title{
ESP Material for Maritime Affairs and Fisheries School in Indonesia
}

\author{
Heriyanti Tahang \\ Universitas Muhammadiyah Sorong, Indonesia \\ Email:heriyanti7@gmail.com \\ Rensi Manuputty \\ Universitas Muhammadiyah Sorong, Indonesia \\ Email: rensimanuputty@gmail.com \\ Kris Uluelang \\ Universitas Muhammadiyah Sorong, Indonesia \\ Email: krisuluelang.ums.@gmail.com \\ Yuliana \\ Universitas Muhammadiyah Sorong, Indonesia \\ Email: Yulianaarsyad23@gmail.com
}

Received: 26 November 2020

Reviewed: 1 May 2021-Aungust 2021

Accepted: 1 October 2021

\begin{abstract}
Identifying English for specific purposes material for particular students is the process of selecting, adjusting, and evaluating English material based on the unique needs of students. Need analysis is needed to identify ESP learning material. This research aimed to identify the students' needs based on goals, necessities, wants, and lacks in learning the English language in Maritime Affairs and Fisheries School using the mixed method with sequential explanatory strategy. Through the purposive sampling, thirty students of the department of fisheries product processing technology at Sekolah Usaha Perikanan Menengah (SUPM) Negeri Sorong became the participants for this research. The recent research used a mixed-method design through a sequential explanatory strategy. Data collection instruments were Guttman scale questionnaires and Focus Group Discussion (FGD. Questionnaires were given to students to determine the goals, necessities, want, and lack of students. The research conducted the FGD to have a more in-depth explanation gathered from the questionnaires' answers. The results showed that ESP material needed by the students of the fisheries product processing technology department was English learning material related to fisheries product processing technology used when having a job. Students were expected to learn ESP topics such as the captain duties, shipping, fisheries, operating machinery, fisheries conversations, cook term, and other English materials correlated with the department of fisheries product processing technology. Therefore, the recent study implied that the teacher must provide ESP material suited to the students' major other than general English to meet the student's need for future work.
\end{abstract}

Keywords: ESP; need analysis, English learning 


\section{Introduction}

ESP is a language teaching approach in which all decisions, such as material and methodology, are based on the learner's reason for learning (Water \& Waters, 1987). Need analysis for ESP courses can be conducted in a vocational school that teaches some particular English fields. Analyzing the students' needs becomes one of the essential concerns to do in order to provide the appropriate English teaching materials.

Need analysis is an initial process of collecting information before a specific course deals with the participants' needs (Nunan, 1989). Many experts said that a need analysis is the process of finding out what the students know and can be studied to know what material needed to be learned. Water \& Waters (1987) simultaneously stated that besides analyzing the needs, an ESP course also needs to determine students' needs, called learning needs. A students' needs analysis emphasizes the students' needs in the language learning process. Need analysis is the first step in a course design. It provides relevancy and validity for all successive course activities designed. It means that need analysis is essential because need analysis is a starting point, especially in designing materials, syllabus, teaching and learning models, and evaluation.

ESP helps students improve their abilities based on their skills and helps them meet their needs in the context of a particular work or study. To benefit from the ESP case, teachers must consider several things related to the teaching and learning process, including the materials used for teaching. Therefore, identifying teaching materials is one of the processes that need to be done.

Identifying teaching materials is selecting, adapting, and evaluating learning material based on the students' specific necessities. For example, to conduct English learning material means supporting the students' competence in English based on the program that they will be mastered or working internationally. Aslrasouli (2012) and Bonabi (2008) concluded that ESP material design requires more consideration to fulfill students' specific academic needs.

Unfortunately, based on the pre-interview done, one of the maritime affairs and fisheries schools in Indonesia, SUPM Negeri Sorong, still provides English material uncorrelated with ESP material. As a result, students learn English without ESP consideration. The materials are general and do not support their knowledge in the department of fisheries product processing technology. The teacher provides general English; the teacher teaches students some technical equipment without telling them the function in English. The material provided was not based on the needs of the students. Most of the English materials used for students in ESP classes are not suited to class intention.

As a vocational school, the materials needed by students must be correlated with the students' program. It is a fisheries product processing technology. According to the national education standards agency for vocational high school, teaching English at school aims to make students proficient in written and spoken language to support their competence in a particular study program. After graduation, the students are expected to work in the fisheries industry both locally and globally. Ideally, English materials used to teach fisheries product processing technology students are relevant to their field. It has been investigated by Chusnul (2001) that what distinguishes ESP from General English is not the presence of a need but a need for awareness. Therefore, it can be stated that the student's needs must be considered in teaching English, especially when teaching English in a particular program.

Some researchers have identified ESP material in a particular program (Miyake \& Tremarco, 2005) and (Pongasapan, 2015) for nursing, (Wulanjani, 2018) for the civil program, (Sari \& Atmanegara, 2018) for accounting students, (Setiawati, 2016) for medical students, (Boroujeni et al., 2013) for educational administration and (Akbari, 2014) for paramedical students 
and practitioners. At the same time, Nurwahida (2017) has researched developing English materials for the management department learners: Export-Import \& banking STIE YPUP. All the previous researches mentioned have the same sight as Morena (2014) in his thesis about need analysis to identify ESP materials. The research concluded that English learning material must be appropriate to reach a satisfactory level in their specialist subject studies. However, from all the previous studies mentioned, a study conducted to identify ESP material on students in maritime affairs and fisheries schools, especially in the department of fisheries product processing technology, is still not found.

Based on the background stated above, the researchers realized that providing English materials for students of the fisheries product processing technology department is essential since the material available is still not relevant. In contrast, the students need English related to the department of fisheries product processing technology. Therefore, research must be conducted to provide ESP material in marine affairs and fisheries school students. For that reason, this recent research aims to find out the students' needs in ESP materials for the department of fisheries product processing technology at SUPM Negeri Sorong, West Papua, Indonesia.

\section{Literature review}

English for a Specific Purposes (ESP) has been a part of English language teaching. Crokers (1981) quoted in Khosiyono (2018) states that teaching ESP courses is actually similar to teaching English in general in the case of the language use emphasized. English for specific purposes is learned by people who need to learn the English language for use in a specific field, such as leisure, medicine, technology, academic learning, and science, etc. Continuously, As a goal-directed language learning, English for specific purposes is not learned because of interest but for specific purposes, such as studying or working or other disciplines (Robinson, 1991). The interest focus is the apparent difference. English for specific purposes focuses on the particular materials that suited a specific discipline.

Hutchinson and Waters (1987) describe that ESP is not a specific teaching methodology; it is a specific teaching material. The view states that Material of English for specific purposes has been the essential skill that the students have for the upcoming workplace based on the students' discipline. As highlighted by Tiongson (2019), mastering discipline-specific communication skills requires the learner to succeed in their future career. Therefore, it can be concluded that ESP material is designed to encounter the specific needs of the learners.

Then Dudley-Evans et al. (1998) state that ESP lies in two aspects. Firstly, ESP teaching material must reflect discipline. It means that the teaching and learning processes would be different based on the discipline taught. Secondly, the language learned must reflect the features of English for specific purposes. Considering the discipline, the ESP material must be generated based on genres, register, and associated language that students need to carry out the correlated activities.

The appropriate ESP material also becomes the main consideration for most ESP teachers. When teaching ESP, the teacher must know the students' field and utilize the English material with the content of a specific discipline. It means that teachers are teaching the English language by engaging the field knowledge with it. It is supported by Brennan \& Naerssen (1989) that even the teachers of ESP have good experience in teaching general English, language knowledge, and various professional fields, but if the teachers do not master the student's field, it will be hard to provide the English materials to stay on the students' field tract. Shannon and Meath-lang (1992) in Tiongson (2019) states that teachers need to contextualize language teaching material based on 
students' disciplines. It can be done by describing the language genres and material that students need to obtain because the collaboration between the ESP and the particular discipline will improve students' English communication skills in their field profession. It will also be challenging for the teacher to improve their professionalism in teaching ESP besides general English.

In addition, the ESP material is not the only main concern in teaching and learning processes. The materials used must be correlated with students' prior knowledge about the discipline. Considering the material, the language input must be the concern in learning English for specific purposes to fulfill the tasks given to students (Hutchinson \& Waters, 1987). So, it needs to consider students' background language ability to assist the students following the class activities well. If the students do not have a basic concept in learning English for specific purposes, students will get some problems. Blackie (1979) in (Dewi 2015) also supported that English for specific purposes must be provided for students who have mastered basic English. Some features are typically dissimilar for particular subjects in learning ESP compared to general English. In fact, General English emphasizes the proficiency of the English language.

At the beginning of designing the course, collecting the students' needs becomes essential. Besides that, assigning the target situation of the language usage is also needed in this stage. Knowing the learners' expectations and the learner proficiency can be collected from the prior selfassessment or discussion between students and instructors to know students' ESP level before teaching ESP (Jordan, 1997). To know the students' needs also might be done by monitoring the professionals who use English at work, interviewing or distributing the questionnaires to the key stakeholder at employment. All the tasks are done to know the particular language proficiency required by the employees in the work setting.

Before teaching an ESP course, the learner's needs must be the primary consideration to conduct. Accordingly, assessing the needs of the students must be conducted as the first stage. Robinson, (1991) has discussed some definition of need. Need is defined as the students' job requirements related to the language course learned. It is also called the goal-directed definition. Need is also referred to what the users need to learn from the language instruction program.

The needs are separated into learning needs and target needs (Water \& Waters, 1987). The target or goals at the same time are what the learners need for a target situation. On the other hand, the learners' needs are what the situation needs to do to learn. The target situation refers to some situations, including the students' necessities, lack, and needs.

After the Goal, Necessity is the next part to consider. Necessities are the need type that is determined by the target situation demands. The learners need to know the function in the target situation effectively (Chusnul 2001). For example, a businesswoman or businessman may need ESP to get the necessary information from sales catalogs, to communicate effectively at sales conferences, and to understand business letters. He or she will also need to know the lexical, linguistic features, structural, and functional used commonly in the identified situations.

To recognize necessities is not enough when the ESP is still concerned with certain students' needs (Water \& Waters, 1987). The students' prior knowledge needs to be known. Because of recognizing the students' basic knowledge, the students' necessities can be assigned well. To do the instruction well in the ESP, teaching and learning process will be dependent on how well the students' prior practices. The target proficiency must be matched with the existing proficiency had by the students. The gap found between both of the proficiencies is called the lack.

Wants is the next part to discuss after the lack term in analyzing the students' needs. Wants in ESP is defined as the learners' view of what to obtain in a language course. Students' wants are also considered the students' insight into the target situation's necessities (Indrasari, 2016). Each 
situation in teaching ESP must be judged according to the particular conditions. Therefore, awareness of the differences is essential for the ESP designer. Furthermore, the differences must be taken into account in ESP material and ESP teaching methodology.

\section{Research method}

This research applied a mixed-method design through a sequential explanatory strategy by analyzing quantitative and qualitative data. This research focused on identifying the students' needs on ESP learning materials in the classroom for fisheries product processing technology descriptively. This research was conducted at SUPM Sorong; it was located in Jl. Klakublik, Sorong City. The research participants were taken using purposive sampling. Thirty students of the fisheries product processing technology department were the participants to fill the Guttman scale questionnaires. Then 18 students were interviewed through focus group discussion. Thus, there were three groups of FGDs consisting of 6 people.

There were four main aspects investigated in the questionnaires. Those were goals, necessities, want, and lack aspects. According to Water \& Waters (1987), the four aspects were the target needs to analyze learner needs. To gather more in-depth data about students' needs, FGD was done after answering the questionnaires. Therefore, the FGDs had been finished after the data were saturated.

To analyze the data, the researcher used the Miles and Huberman technique. They were; data reduction, data display and concluding, then verification. First, the questionnaires were analyzed by calculating the percentage of students' answers. Then, it was calculated to know the dominant answer to the questionnaire. While the data gathered from FGDs were used to triangulate the data collected from the questionnaires.

\section{Finding and discussion}

The data collected from the questionnaires and FGD as the instrument had been reduced by coding the data based on the four main aspects. They were the goals, necessities, wants, and lacks. After that, data displayed based on those aspects using a chart then concluded. The results are described as follow:

\section{Goal}

Based on the questionnaire's answer, the highest percentage was found in question number 4 (Q4) that $90 \%$ of students of the department of fisheries product processing technology stated that they learned English because they were intended to communicate using English for their work. Then, $73.3 \%$ of students stated that they liked English material related to the field of fisheries (Q13). While the students who learned English to master the use of specialized terms in fisheries were $66.7 \%(\mathrm{Q} 10)$, and 53\% of the students learned English to support their future work (Q6). It can be summarized that students' purpose in learning English in the Maritime Affairs and Fisheries department is to communicate using English to support their future work. So, they want to learn English suited to their major. The data shows in Figure 1. 


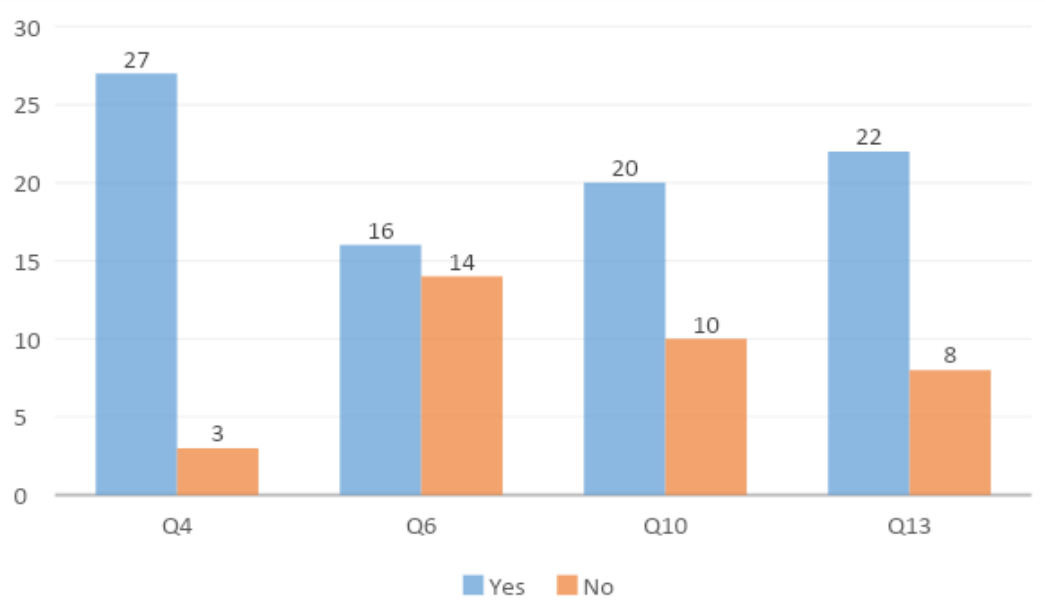

Figure 1. The Result of Questionnaires in Aspect of Goal

\section{Communicating at work}

FGD conducted supports the result of the questionnaires. Based on the interview results, the students also added the answer related to the significance of learning English as communication tools for future work.

Participant

Student 2 from FGD 1

Student 6 from FGD 2

Student 6 from FGD 3

\section{Extracts}

We need to learn English to look for a job easier;

I learn English to improve my insight about foreign people to sell my product easier globally;

I learn English to support my product spreading out into other cities internationally.

The extracts above showed that students intended to use English for work even for having international work after learning it. The student 2 in FGD 1 desires to find a job easier as the goal of learning English. While both of the students 6 from FGD 2 and FGD 3 express that they want to learn English for spreading their products internationally.

As stated previously, ESP is learned to pursue specific goals. All the students learning in a vocational school have a purpose for sharpening a specific skill proposed by the school curriculum, including in learning English. Hence, English syllabus also has been the following term that must be suited to the school specific goals. It is because every language program has its aims such as developing basic communication skills to use at the workplace (Richards, 2001). Moreover, English is really needed internationally because English as a Lingua Franca (ELF), commonly called as a global language, has been a means of business communication among speakers whose first language is not English around the world (Vijay, 2012). Importantly, this finding implied that providing English correlated with students' major would be beneficial for provisioning their future career globally by having a good English communication skill.

\section{Learning English suited major}

As the second highest percentage for students' goals in learning English, the data collected through FGD illustrated the same views. Here are the students' statements from the interview; 


\section{Participant Extracts \\ Student 5 from FGD 2 Such as learning vocabulary about the fisheries' equipment, machines, filleting fish, the hygiene terms, and marketing vocabulary; \\ Student 1 from FGD 3 I need English learning material such as vocabulary about kitchen set, ship, and machines; \\ Student 1 from FGD 3 Such as pisciculture, the way to feed fish, how to maintain fish, and its feed seeds; \\ Student 4 from FGD 2 Topics such as Filleting Fish, separating the fish's skin, meat and bone using English.}

The data above showed that the students were expected to learn English related to fisheries product processing technology. It was noted by Widodo (2016) that students in vocational school should build vocational knowledge and skills. This significantly implied that English language learning in vocational school should cater to the diversity needs of vocational students. Furthermore, The material provided must be suited to the students' specific major at school. In different fields in the same case, Mahbub (2021) also reported that most students in Computer Engineering and Network were expected to learn English relevant to their program curriculum. The same result in different significance was also found by Musikhin (2016) in his research that Mastering ESP correlated with students' program was essential to be a contributive player in the international competitive world.

Based on the data gathered, the students' goal in the fisheries product processing technology department is to learn ESP material related to their major to be applied communicatively in their work, even written or spoken. On the other hand, they are intended to learn English to support their specific academic needs related to their program.

\section{Necessities}

As Chusnul (2001) stated, 'Necessities' could be called as the type of need determined by the demands of the target situation. Necessities refer to what the learners have to know to function effectively in the target situation. The questionnaire was designed to know the students' view about the essential of learning English. Based on Figure 2, the questionnaires concluded that $90.0 \%$ of the students said that English was essential (Q2). Then, 70.0\% of students have a demand to like learning English (Q1), and 66.7\% students intended to participate actively in the English learning process (Q12). Moreover, 36.7\% of students answered that the teacher's material is still within their degree (Q8). 


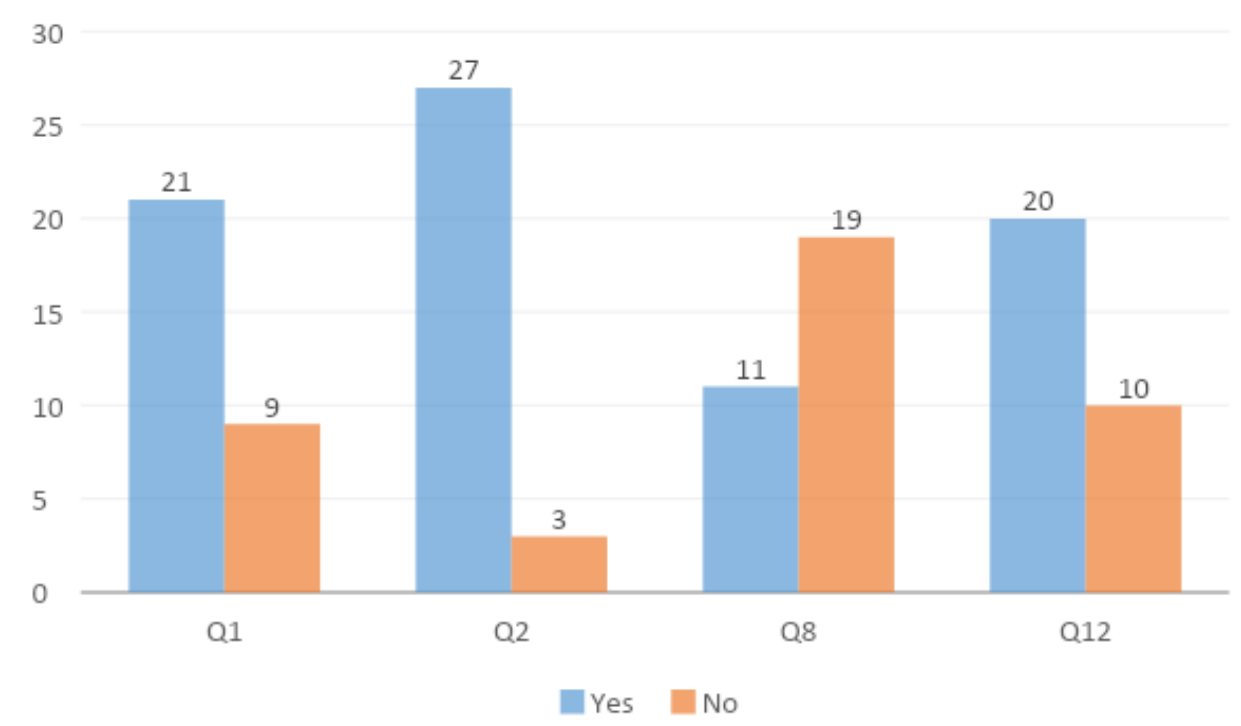

Figure 2. The Result of Questionnaires in Aspect of Necessities

Learning English is a necessary

The necessities of learning ESP also have been discussed in FGD to support the data from the Questionnaires. these are the students' discussion result;

Participant

Student 3 from FGD 3

Student 6 from FGD 1

Student 1 from FGD 1

Student 6 from FGD 3

Student 3 from FGD 2

Student 6 from FGD 1

\section{Extracts}

It is very important for our major because it will support our career; We really need English vocabulary supporting our major; I am interested because English is an international language, so we need to learn it;

I do not participate in the classroom because I think that I need English material or vocabulary related to my major not the general one;

We learn English generally such as learning English Present Tense only;

We still learn general English whereas we need English suited to our major.

Based on the students' questionnaires and interview results above, it can be concluded that the majority of students in the department of fisheries product processing technology in the Fisheries Product and Processing program believed that learning English was necessary for them. It was proved that most of the students liked and tried to participate in learning English. Unfortunately, the students are still learning English in General Context. In a previous research, Sari \& Atmanegara (2018), who has developed ESP material for the Accounting Program, has revealed that after using the ESP material developed, the students' ESP reading skills in the Accounting Program improved. It means that when the students learn ESP material related to their major, they will have a chance to develop their ESP skills even if only for a certain skill. 
Want

In the term of want in students need analysis, the questionnaire's result showed that $93.3 \%$ of students expected learning English would enable them to understand its vocabulary, meaning, and pronunciation of fisheries dictions (Q15). Furthermore, $70.0 \%$ of students wanted to learn English by practicing more (Q9). Then, $70.0 \%$ of students needed the task assigned according to their major in the learning process (Q14). Furthermore, $40.0 \%$ of students wanted to study English material using many pictures as teaching and learning media (Q5). The data can be seen in Figure 3.

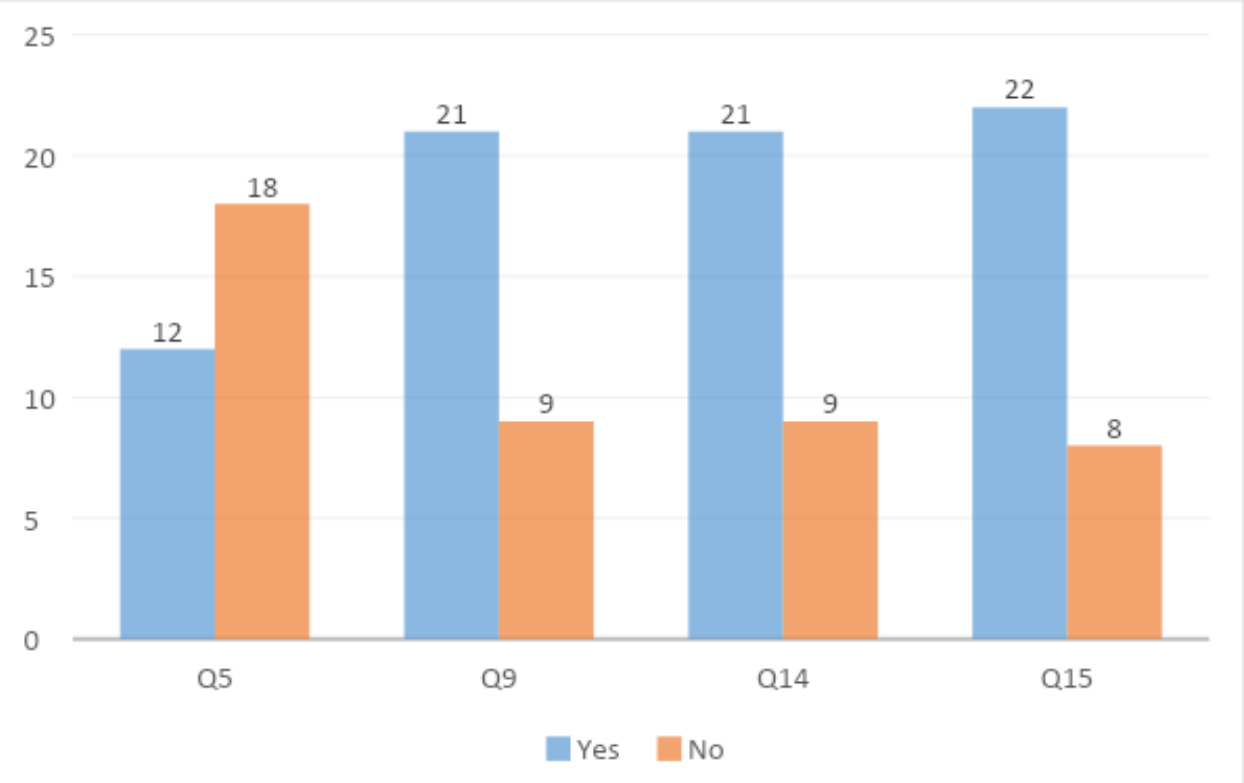

Figures 3. The Result of Questionnaires in Aspect of Want

Understanding vocabulary related term functionally

All of the students' arguments in FGD also support the data mentioned in Figure 3 . The statements are:

Participant

Student 3 from FGD 2

Student 1 from FGD 2

Student 5 from FGD 2

Student 3 from FGD 2

Student 6 from FGD 3

Student 1 from FGD 2

\section{Extracts}

We are supposed to learn English related to our major, such as learning fisheries vocabulary that is needed when working in fisheries factories because fisheries mostly used English terms;

Of course, we need to learn fisheries terms such as cultivation, pisciculture, and fish seed maintenance;

Of course, we need more practice because we're always asked using English when we go field practicing;

I want tasks related to my major, not only assignments based on the textbook;

The teacher provides us with assignments which are not assigned according to our major;

We need Pictures in learning English to understand the meaning of the vocabulary, but the teacher almost always uses text in teaching English all the time. 
These results revealed that the students wanted to learn English to enrich their vocabulary mastery and pronunciation, such as terms related to tools used in fisheries technology and maintenance of all vocabularies related to fisheries. Besides that, they intended more practice when learning English because practicing would push them to be better in English. They also prefer to have the tasks related to their department of fisheries product processing technology. Even they were expected to learn English with many pictures as the media to understand the English Vocabulary well. related to this finding, in different majors, Wulanjani (2018) also researched the need analysis on ESP material for Civil Engineering. The research found that students of Civil Engineering considered having more practice in learning English and learning all about the major in English. As mentioned before, it's really necessary to provide ESP material related to the students' program. And practicing to use the material communicatively in the classroom also became a requirement mentioned by Shannon and Meath-lang (1992) in Tiongson (2019) \& by Dudley-Evans et al. (1998) before.

Lack

Knowing the lack had by the students also helped to decide students' necessities in learning ESP material. In other words, the target proficiency needed to be matched and compared to the learners' existing proficiency. The gap between them could be denoted as the learner lacks.

The data from the questionnaire answered by 30 students of the fisheries product processing technology department revealed that $76.7 \%$ of English skills needed to be improved (Q3). Then, $76.7 \%$ of students still had difficulty in finding an English vocabulary (Q7). While 56.7\% answered that the English curriculum at school still did not support their department because they still learn general English (Q11). Look at figure 4. to see the data.

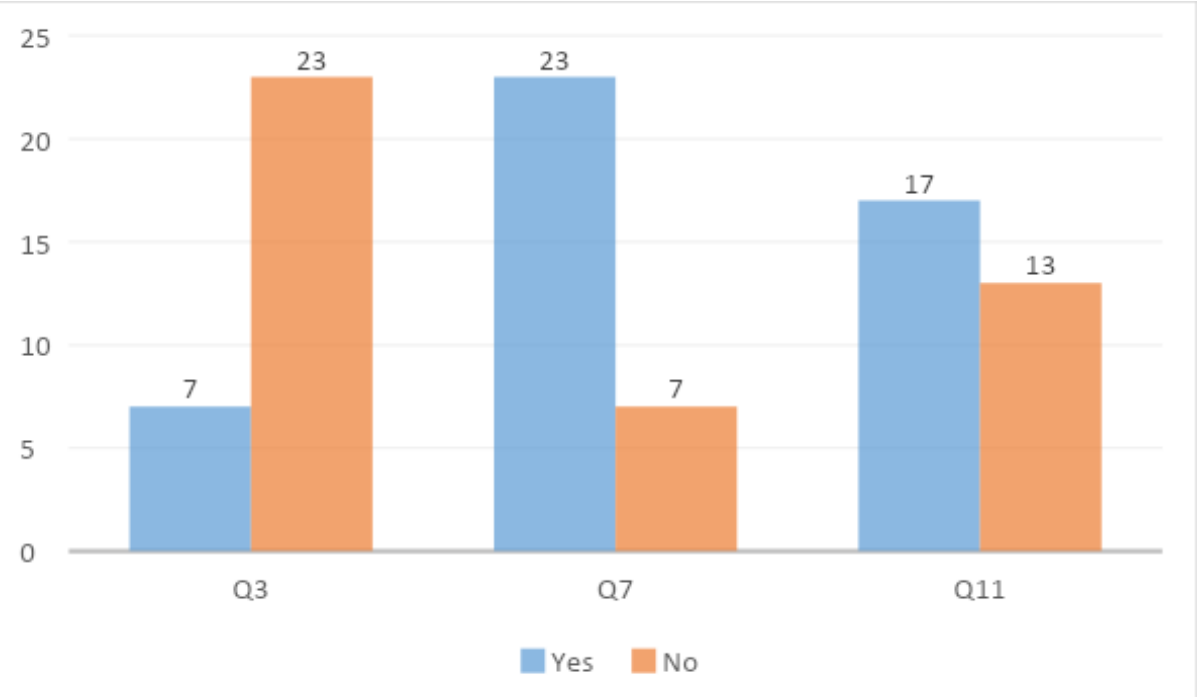

Figures 4. The Result of Questionnaires in Aspect of Lack

English skill

Participant

Student 2 from FGD 1

\section{Extracts}

My English has not improved yet because the teacher still teaches the general English that I do not want; 
Student 1 from FGD 3

Student 6 from FGD 3

Student 4 from FGD 1

Student 4 from FGD 2
Because the teacher teaches English according to the fisheries material;

I still have a limited ability in English. I can not read the English text well because the written and its pronunciation are different;

Student 2 from FGD 3 I do not understand the vocabulary because the pronunciation and its written are different;

The curriculum also become the weakness because it is not following our major;

Specific English is needed by us, but the teacher only teaches us English in general.

As stated by the data that the students still had much weakness in mastering English personally, even the material comes from the school curriculum. So, analyzing the students' needs must be conducted to design English material to meet the students' needs. This research has been associated with the research done by Sihmirmo (2015), Zuana (2014), Pongasapan (2015) that the English material must be developed based on the needs of the students. beside that considering the students' prior ability also must be other consideration before assigning the ESP teaching and learning process as stated by Blackie (1979) in (Dewi 2015) and (Hutchinson \& Waters, 1987) that the Student's language input must be one of the main consideration in designing the ESP material for a specific major. Swales (1989), cited in Rahman (2015), also added that the keys feature of ESP were (1) providing a particular task which focuses on the language context; (2) involving students' prior knowledge related to the profession learned; (3) focus on the communicative and operational syllabus; and (4) students' center. Accordingly, recognizing the students' lack must be a preliminary design before teaching an ESP in the classroom.

\section{Conclusion}

The previous chapter's discussion concludes that the eleventh grade of the fisheries product processing technology department needs more specific English material related to fisheries. The English material matched based on their goal, necessity, want, and lack. First, the student stated that they learned English because they want to communicate in the fisheries workplace. Then the students' department of fisheries product processing technology said that their necessity in learning English is an English material related to fisheries. The skill they wanted to increase due to most fisheries activity using the speaking skills such as offering fisheries products. Speaking skills also became the desire of fisheries students. Students also stated that practicing English through speaking was their significant weakness. Therefore, to maximize their competence, thirty fishery students hoped that the school would design an ESP Material in learning English.

Based on the conclusion above, it is suggested that the teacher design the ESP material that is appropriate for students of the department of fisheries product processing technology. It is because the students need to learn English related to their discipline. Moreover, the teacher also needs to overcome students' speaking skill weaknesses by providing more activities to strengthen students' speaking competence.

The researcher did not conduct this study without limitations. The limited-time when conducting this research caused only six students to be interviewed in 3 FGDs. Thus, the data were restrained with 18 of 30 students. Future research is suggested to research by expanding many students and developing an ESP curriculum for fisheries product processing technology students.. 
Declaration of conflicting interest

The authors declared no potential conflicts of interest in this work concerning the research, authorship, and publication of this article.

Funding acknowledgement

This research received no external funding.

\section{References}

Akbari, Z. (2014). Academic English Needs of Iranian Paramedical Students and Practitioners: an Esp Context. International Journal of Language Learning and Applied Linguistics World, 5(2), 274-286. http://www.ijllalw.org/finalversion5222.pdf

Aslrasouli, M. (2012). Challenging One-Size-Fits-All Approach in ESP Material Design: Insights from Iran \& India. Procedia - Social and Behavioral Sciences, 69(Iceepsy), 1374-1382. https://doi.org/10.1016/j.sbspro.2012.12.075

Bonabi, V. F. (2008). The Importance of Materials Design in ESP and EST. Journal of Applied Linguistics, 1(3), 39-61.

Boroujeni, S. A., Fard, F. M., \& In, M. A. (2013). A Needs Analysis of English for Specific Purposes (ESP) Course For Adoption Of Communicative Language Teaching :( A Case of First-Year Iranian Students of Educational Administration). International Journal of Humanities and Social Science Invention ISSN, 2(6), 35-44. www.ijhssi.org

Brennan, M., \& Naerssen, M. van. (1989). Language and Content in ESP. ELT Journal, 43(July). Chusnul. (2001). Development of English material. Cambridge University Press.

Dewi, S. U. (2015). Syllabus of Vocational High School Based on ESP Approach. Dinamika Ilmu, 15(2), 273. https://doi.org/10.21093/di.v15i2.73

Dudley-Evans, T., St John, M. J., \& Saint John, M. J. (1998). Developments in English for specific purposes: A multi-disciplinary approach. Cambridge university press. https://books.google.co.id/books?hl=id\&lr=\&id=FY5ChNRKtxwC\&oi=fnd\&pg=PR8\&d $\mathrm{q}=$ Developments + in + English + for + Specific + Purposes: $+A+$ MultiDisciplinary+Approach+Tony+DudleyEvans\&ots=hgf9w9Oq2C\&sig=pAaciRNh2EkqDK3ruLrqz07pTO4\&redir_esc=y\#v=one page\&q=Developments

Mahbub, M. (2021). English teaching in vocational high school: a need for analysis.

Indrasari, N. (2016). English for Specific Purposes: A Need Analysis at The Second Semester of Physics Education Students of IAIN Raden Intan Lampung in The Academic Year of 2015/2016. English Education: Jurnal Tadris Bahasa Inggris IAIN Raden Intan, 9(1), 161172.

Jordan, R. R. (1997). English for academic purposes: A guide and resource book for teachers. Cambridge University Press. https://books.google.co.id/books?id=Ywe7sKTTQ9UC\&printsec=frontcover\&dq=Jordan ,+ R. + R. $+(1997) .+$ English + for+academic + purposes: + A+guide+and + resource+book + for $+t$ eachers. + Cambridge + University + Press. \&hl=id\&sa $=$ X\&ved=2ahUKEwiN1PbQ6dLuAh XK7HMBHVI-C9IQ6AEwAHoECAMQAg

Khosiyono, B. H. C. (2018). Topic-Based Esp Materials for Vocational School. Prominent, 1(1), 4-11. https://doi.org/10.24176/pro.v1i1.2486

Miyake, M., \& Tremarco, J. (2005). Needs Analysis for Nursing Students Utilizing Questionnaires and Interviews. Kawasaki Journal of Medical Welfare, 11(1), 23-34. 
Morena, B. (2014). Teaching English for Specific Purposes and Teacher Training. European Scientific Journal, 10(2), 40-49.

Musikhin, I. A. (2016). English for Specific Purposes: Teaching English for Science and Technology. ISPRS Annals of Photogrammetry, Remote Sensing and Spatial Information Sciences, III-6(July), 29-35. https://doi.org/10.5194/isprsannals-iii-6-29-2016

Nunan, D. (1989). Designing Tasks for the Communicative Classroom. Cambridge University Press.

Nurwahida. (2017). Developing English Materials For Students Of Management Department Export-Import \& Banking at STIE YPUP.

Pongasapan, P. N. (2015). Needs Analysis of Instructional Materials for English Speaking Skills for Nursing Students at STIKES Toraja. Jurnal KIP, IV(1), 749-758.

Rahman, M. (2015). English for Specific Purposes (ESP): A Holistic Review. Universal Journal of Educational Research, 3(1), 24-31. https://doi.org/10.13189/ujer.2015.030104

Robinson, P. C. (1991). ESP today: A practitioner's guide. Prentice Hall. https://books.google.co.id/books?id=rsBnQgAACAAJ\&dq=ESP+today:+A+practitioner $\% 27 \mathrm{~s}+$ guide. + Prentice + Hall\&hl=id\&sa=X\&ved=2ahUKEwikl4OU6NLuAhVmIbcAHd9 BBJIQ6AEwAHoECAAQAQ

Sari, F., \& Atmanegara, Y. (2018). Developing ESP Reading Materials for Accounting Students. Advances in Language and Literary Studies, 9(5), 1. https://doi.org/10.7575/aiac.alls.v.9n.5p.1

Setiawati, B. (2016). Need Analysis for Identifying Esp Materials for Medical Record Students in Apikes Citra Medika Surakarta. Kajian Linguistik Dan Sastra, 1(1), 62. https://doi.org/10.23917/kls.v1i1.2479

Sihmirmo, P. (2015). The needs analysis of English learning for the fourth and fifth graders. Eduscience, 1(1), 41-61.

Tiongson, M. T. A. (2019). English for Specific Purposes Teachers' Perceptions of Interdisciplinary Collaboration in Writing Classes. Journal of English Studies and Comparative ..., 113-127. https://tmc.upd.edu.ph/index.php/jescl/article/view/6906

Water, H., \& Waters, A. (1987). English for Specific Purposes. Cambridge University Press. https://books.google.co.id/books?hl=id\&lr=\&id=s2FIpUv7gaoC\&oi=fnd\&pg=PR8\&dq= English + for + Specific + Purposes. + Cambridge:+Cambridge+University+Press.\&ots=RiDAxnmxZ\&sig=OA2V-

m1WWEU1Ip6uBkTmXuvNO5s\&redir_esc $=y \# v=$ onepage $\& q=$ English $\quad$ for $\quad$ Specific Purposes. Cambridge

Widodo, H. P. (2016). Teaching English for specific purposes (ESP): English for vocational purposes (EVP). In English language teaching today (pp. 277-291). Springer, Cham.

Wulanjani, A. N. (2018). Exploring Students' Need for Developing Material of English for Civil Engineering. Metathesis: Journal of English Language, Literature, and Teaching, 2(1), 1. https://doi.org/10.31002/metathesis.v2i1.552

Zuana, M. (2014). The role of needs analysis in teaching ESP for nursing. The 61 TEFLIN International Conference, UNS Solo, 2014, 130-134. 